A very slight alteration of the number of vertebræ in trout is possible, however, in developmental stages even somewhat older than about 170 day-degrees, that is, roughly after the first fine pigment has begun to show in the eyes; this slight alteration has in all experiments hitherto carried out been less than about 0.2 vertebræ and seems to be connected with slight morphological alterations in the arches to the last but four vertebræ (that is, in the so-called fused vertebræ near the tip of the tail). In most cases, however, no alteration is observed in embryos older than about 170 day-degrees.

I suppose that the results achieved may prove to be valid for teleosts generally, thus suggesting that the number of vertebræ is fixed before hatching in our common food fishes. Determination of the final number of vertebræ must, in consequence of the mode of development, occur (for example, in cod, plaice and herring) during the first half to two thirds of the incubation period; this knowledge is of course valuable for studies in racial characters used in applied fishery biology. It is, moreover, of interest to see that a quantitative character (number of vertebræ) is comparable to several qualitative characters determined already in the very early stage of the developing egg, for example, in Amphibia, in which it has been shown that morphogenetic stimuli are emitted by an organiser during gastrulation. The great effect met with in the supersensitive period may probably be compared with the effect which Goldschmidt found in Drosophila, the result being the so-called 'phenocopies'.

Various other experiments carried out on sea-trout have revealed the fact that such other meristic characters as the number of fin rays in the dorsal, anal and pectoral fins are determined in a very early stage too, mainly previous to hatching. It has furthermore been possible to show that, besides temperature, oxygen pressure has a determining effect on the number of vertebræ, though it is small (low pressure gives a higher number of vertebræ); other environmental factors affecting the number of vertebræ have not yet been found; but it must be pointed out that research work in experimental racial studies in teleosts is still in its infancy; much more work is necessary before even the main problems are settled ${ }^{7}$.

${ }^{1}$ Inubbs, C. L., Amer. Naturalist, 68 (1934).

- Gabriel, M. L., J. Exp. Zool., 95, 105 (1944).

Johnsen, S., Bergens Museums Árbok, No, 4, 2 (1934)

'Mottley, C. MoC., J. Biol. Board of Canada, 111, 169 (1937).

"Schmidt, J., "Racial Investigation VII-VIII", C.R. Trav. Lab. Carlsberg, 14 (1921).

- Táning, A. Vedel, Medd. Komm. Danmarks Fisheri- og Havunders : Fiskeri, 11, 3 (1944).

' Vladykov, V. D., Trans. Roy. Canad. Inst., 20, 99 (1934) (review of literature).

\section{EFFICIENCY OF FOREST ENUMERATIONS}

$\mathrm{A}^{\mathrm{T}}$

$\mathrm{T}$ the present juncture in forestry matters and the available stocks of timber in the world's forests, it would be difficult to over-estimate the value of the discussion which took place at the sixth Sylvicultural Conference held at Dehra Dun, India, in April 1945 on "The Efficiency of Enumerations". Indian Forest Leaflets (Sylviculture) Nos. 83, 84 and 85 (Forest Research Institute, Dehra Dun, U.P. 1945) deal with the resolutions made at the Conference and the progress so far achieved. The reason for instituting the investigations in India was due to the extra fellings rendered necessary in the well-managed forests by war demands. If such irrvestigations are held to be so urgent in India, where so large a proportion of the State forests are under working plans, the position in large parts of the world's forests outside India where unrestricted war fellings have been carried out in the absence of any detailed knowledge of what the forests contained, or to what degree they were being over-felled, may be imagined. These leaflets come at a most opportune moment.

Leaflet No. 1 (I. The Problem) details the problem as follows :-(1) The general over-felling of the forests of India and in particular the felling of special sizes of selected species for war purposes has rendered it imperative that, as soon as the War is ended, large-scale enumerations be carried out in a number of provinces for working-plan purposes in order to estimate war damage and remaining resources. (2) Enumerations will also be necessary to provide for post-war planning. (3) The accuracy of enumerations is a matter of permanent importance. (4) At present we have little or no information of the potential accuracy of current methods of enumeration. (5) It appears probable that much useful information can be obtained fairly quickly by examination of existing data.

The Conference therefore resolved that: (I) the central sylviculturist be authorized to proceed at once with the examination of existing data, to endeavour to give an indication as soon as possible of the probable accuracy of different methods and intensities of enumeration in different types of forest and terrain; (2) approximate information is needed quickly rather than a more detailed accurate complete research; (3) the staff used for enumeration work should be of the highest quality available, and should receive extra remuneration; (4) after the examination of this data a paper or leaflet should be written on the necessity for determining the precision of sampling enumerations.

As a result work was started-Leaflet No. 84 (II. Madras Tropical Wet Evergreen Forest; III. Typical Calculations) discusses briefly the area concerned and the data available, and shows the errors in estimations of total volumes which would have occurred had "sampling enumerations of different intensities been carried out instead of a full 100\% enumeration". It is emphasized that this investigation is the first of its kind in India and only deals with one type of forest. The points of chief importance are as follows. (1) Intensive and expensive 100 per cent enumerations are not necessary in order to obtain a reasonable estimate of the growing stock. Enumerations of 5-10 per cent are probably sufficient for most practical purposes.... (3)'Whatever the intensity of enumeration, some thirty to sixty separate estimates of the volume per acre in each square mile of forest will probably give a sufficiently accurate estimate of the total volume and the precision of the calculation. This is an economically reasonable number of figures for the computors to handle.

In Leaflet No. 85 (IV. Madras Moist Mixed Deciduous Forest) the following indications are given as results from the investigations so far carried out: (1) Intensive and expensive 100 per cent enumerations are not necessary in order to obtain a reasonable estimate of the growing stock. For practical purposes enumerations of 5 or 10 per cent in evergreen, and of $2 \frac{1}{2}$ or 5 per cent in moist deciduous forest are probably sufficient.... (3) Whatever the intensity of enumeration, 
some thirty separate estimates of the volume per acre in each square mile of evergreen forest and some ten separate estimates per square mile in moist deciduous forest will probably give a sufficiently accurate estimate of the total volume. These are both economically reasonable numbers of figures.

A careful study of these leaflets is strongly to be recommended to all those in charge of forest areas which have been subject to these disastrous and, in many cases, almost unchecked war fellings, admittedly practically inevitable with a war including and affecting the whole globe. India has started a wholesale stock-taking in her forests. Yet India with her highly developed network of working plans covering the State forests is probably in a far better case of knowing what is the position of the over-felling, the excess war fellings, than are most countries where forests have been subject to these heavy drains.

\section{PLANT PHYSIOLOGY IN THE U.S.S.R.*}

\author{
By Prof. ERIC ASHBY \\ University of Sydney
}

\section{Laboratory of Photosynthesis}

$\mathrm{O}$ UTSIDE the Institute of Plant Physiology re* search is going on in many other plant physiology laboratories. There is an independent laboratory of photosynthesis in the Academy, under Academician A. A. Richter. The laboratory has four workers: Richter, who is seventy-four; and three others, including K. T. Sukorukov. Richter's wife, who is well known under her own name of T. A. Krassnocelskaya, has the chair of plant physiology at the Pedagogical Institute in Moscow. In this laboratory photosynthesis is measured from disks of leaves in a Warburg apparatus. Recently ${ }^{27,28}$ Richter and his co-workers have surveyed the relationship between photosynthesis and growths in some dozen different plants. They find that over long periods the photosynthetic rate remains unchanged, despite changing growth-rate and accumulation of dry matter; and it is independent of polyploidy, nitrogen-level, and length of day. These results are not simply the consequence of the controlling action of carbon dioxide under natural conditions, for in some experiments the carbon dioxide level was as high as 0.2 per cent. Richter has also surveyed the photosynthetic rates of plants of very different taxonomic positions (for example, Ginkgo, ferns), and he reports some large differences among them. Other lines of work in this laboratory are plastid chemistry and the physiology of immunity.

\section{Komarov Botanical Institute of the Academy of Sciences}

This institute is concerned primarily with taxonomy (under Shishkin), plant geography (under Ilyinsky and Lavrenko), and anatomy (under Alexandrov); but there is a plant physiological laboratory where Lubimenko's work is continued by Brilliant. She is studying the effects of dehydration of the leaf on the rate of photosynthesis. A recent publication ${ }^{28}$ confirms her earlier work, that in some circumstances there is an increase of photosynthesis after partial

* Continued from page 558. dehydration of the leaf. In the same laboratory Ermolaeva has worked on the effects of coloured light of different photoperiods on the growth of Perilla ${ }^{30}$.

\section{Vernadsky Laboratory of Geophysical Problems, Academy of Sciences}

This laboratory was made famous by the work of the late Academician Vernadsky, and it is now under the direction of Vinogradov. Several problems of interest to plant physiologists are under investigation, notably E. A. Boychenko's work on the activity of chloroplasts outside the cell ${ }^{31}$. Using chloroplasts from white clover, deposited on filter paper, and working at an $r \mathrm{H}$ less than 10, with a hydrogen donator, Boychenko has produced several ml. of oxygen. Activity continues over 2-3 days. This laboratory has worked also on the mineral content of Lemna from various parts of the world, and the detection of rare elements by the most refined modern techniques.

\section{People's Commissariat of Agriculture}

Among the many hundreds of research institutes and stations under this commissariat there are several where plant physiological research is being conducted, notably the Institute. of Plant Industry and the Institute of Physico-Agronomy in Leningrad, the Institute for Grain Culture at Nemchinovko, near Moscow, and the Institute for Grain Husbandry at Saratov.

In the field station of the Institute of Plant Industry, at Pushkin, near Leningrad (founded by Maximov in 1924), Rasumov works, though he is at present away on military service. The Institute of Physico-Agronomy is under the famous physicist, Joffe, and it is engaged in extremely interesting work on the application of physical methods to crop physiology and soil science. Kolyasev is working on the movements of water in soile. Malchevsky, who died of starvation as a result of the siege of Leningrad, did some excellent work on photo-induction ${ }^{32}$. Joffe's assistants are engaged on the design of ingenious instruments for measuring leaf temperature, soil surface temperature, and heat transmission through soils; and they plan to work now on the measurement of soil moisture by the use of bighvelocity neutrons which are transformed to lowvelocity neutrons by water in the soil. Moshkov is working on lines similar to those of Chailachjan ${ }^{33}$. $\mathrm{He}$ concludes from his experiments that there is not yet sufficient evidence for belief in the existence of flower hormones. Some of his recent experiments provide analyses of the effect of length of day on drought resistance, on frost resistance, and on dwarf forms in willows; and he has studied in a series of brilliant experiments the infiuence of short day on parts of leaves, and on old and young leaves, in Perilla. Among several interesting results he has obtained is that an old leaf requires about three times as long a period of photoperiodic induction as a young leaf, in order to produce the same effect on flowering.

In the Institute of Grain Culture, Vassilyev (well known for his work on transpiration and recently on vernalization) is now studying frost resistance ; and he has recently published work on phasic develop. ment ${ }^{34}$. In the Institute of Fodders there is work on the mineral nutrition of grasses and the biology of pollination of lucerne. In the Institute of Grain 